\title{
When it is Reasonable for Europeans to be Confused: Understanding when a Disability Accommodation is 'Reasonable' from a Comparative Perspective
}

Citation for published version (APA):

Waddington, L. B. (2008). When it is Reasonable for Europeans to be Confused: Understanding when a Disability Accommodation is 'Reasonable' from a Comparative Perspective. Comparative Labor Law \& Policy Journal, 29(3), 101-124.

Document status and date:

Published: 01/01/2008

\section{Document Version:}

Publisher's PDF, also known as Version of record

\section{Document license:}

Taverne

Please check the document version of this publication:

- A submitted manuscript is the version of the article upon submission and before peer-review. There can be important differences between the submitted version and the official published version of record.

People interested in the research are advised to contact the author for the final version of the publication, or visit the DOI to the publisher's website.

- The final author version and the galley proof are versions of the publication after peer review.

- The final published version features the final layout of the paper including the volume, issue and page numbers.

Link to publication

\footnotetext{
General rights rights.

- You may freely distribute the URL identifying the publication in the public portal. please follow below link for the End User Agreement:

www.umlib.nl/taverne-license

Take down policy

If you believe that this document breaches copyright please contact us at:

repository@maastrichtuniversity.nl

providing details and we will investigate your claim.
}

Copyright and moral rights for the publications made accessible in the public portal are retained by the authors and/or other copyright owners and it is a condition of accessing publications that users recognise and abide by the legal requirements associated with these

- Users may download and print one copy of any publication from the public portal for the purpose of private study or research.

- You may not further distribute the material or use it for any profit-making activity or commercial gain

If the publication is distributed under the terms of Article 25fa of the Dutch Copyright Act, indicated by the "Taverne" license above, 


\section{HEINONLINE}

DATE DOWNLOADED: Tue Sep 14 05:18:59 2021

SOURCE: Content Downloaded from HeinOnline

Citations:

Bluebook 21st ed.

Lisa Waddington, When It Is Reasonable for Europeans to be Confused: Understanding When a Disability Accommodation Is Reasonable from a Comparative Perspective, 29 COMP. LAB. L. \& POL'y J. 317 (2008).

ALWD 6th ed.

Waddington, L. ., When it is reasonable for europeans to be confused: Understanding when a disability accommodation is reasonable from a comparative perspective, 29(3) Comp. Lab. L. \& Pol'y J. 317 (2008).

APA 7th ed.

Waddington, L. (2008). When it is reasonable for europeans to be confused: Understanding when disability accommodation is reasonable from comparative perspective. Comparative Labor Law \& Policy Journal, 29(3), 317-340.

Chicago 17th ed.

Lisa Waddington, "When It Is Reasonable for Europeans to be Confused: Understanding When a Disability Accommodation Is Reasonable from a Comparative Perspective,"

Comparative Labor Law \& Policy Journal 29, no. 3 (Spring 2008): 317-340

McGill Guide 9th ed.

Lisa Waddington, "When It Is Reasonable for Europeans to be Confused: Understanding When a Disability Accommodation Is Reasonable from a Comparative Perspective" (2008) 29:3 Comp Lab L \& Pol'y J 317.

AGLC 4th ed.

Lisa Waddington, 'When It Is Reasonable for Europeans to be Confused: Understanding When a Disability Accommodation Is Reasonable from a Comparative Perspective' (2008) 29(3) Comparative Labor Law \& Policy Journal 317.

MLA 8th ed.

Waddington, Lisa. "When It Is Reasonable for Europeans to be Confused: Understanding When a Disability Accommodation Is Reasonable from a Comparative Perspective." Comparative Labor Law \& Policy Journal, vol. 29, no. 3, Spring 2008, p. 317-340. HeinOnline.

OSCOLA 4th ed.

Lisa Waddington, 'When It Is Reasonable for Europeans to be Confused: Understanding When a Disability Accommodation Is Reasonable from a Comparative Perspective' (2008) 29 Comp Lab L \& Pol'y J 317

Provided by:

Maastricht University Library

-- Your use of this HeinOnline PDF indicates your acceptance of HeinOnline's Terms and Conditions of the license agreement available at https://heinonline.org/HOL/License 


\title{
WHEN IT IS REASONABLE FOR EUROPEANS TO BE CONFUSED: UNDERSTANDING WHEN A DISABILITY ACCOMMODATION IS "REASONABLE" FROM A COMPARATIVE PERSPECTIVE
}

\author{
Lisa Waddington $\dagger$
}

\section{INTRODUCTION}

The Employment Equality Directive, ${ }^{1}$ adopted by the European Community in 2000, has resulted in radical revisions and extensions to the employment non-discrimination laws of all twenty-seven Member States. The Directive required Member States to legislate to prohibit employment discrimination on the grounds of religion or belief, age, sexual orientation, and disability, ${ }^{2}$ and one consequence of this process has been the introduction of the concept of a "reasonable accommodation" in favor of disabled individuals into the national legal systems. This requirement is found in Article 5 of the Directive, which obliges Member States to impose a duty on employers to make

$\dagger$ European Disability Forum Chair in European Disabılity Law, Maastricht University, the Netherlands. The research on which this article is based was carried out within the framework of the European Community funded project: Stimulating Public Interest Littgatton at a Pan-European Level-Raising Knowledge and Imparting Skills Project, which was supported by the Community Action Programme to combat discrimination. A key result of the project was the casebook CASES. MATERIals and TEXT ON NATIONAL. Supranational and INTERNATIONAL NON-DISCRIMINATION LAW (D. Schiek, L. Waddington \& M. Bell eds., 2007). The project involved over fifty academics from throughout Europe and a team of professional translators, and was initiated by the author. Unless otherwise specified, the translations used in this article resulted from this project. For further information on the casebook project see http://www.casebooks.eu/nondiscrimination (last visited Jan. 6. 2008).

1. Council Directive 2000/78/EC. 2000 O.J. (L303/16) (EU) (Directive establishing a general framework for equal treatment in employment and occupation).

2. The year 2000 also saw the adoption of a second non-discrimination directive addressing discrimination on the grounds of race and ethnic origin in the area of employment as well as a number of other areas. Council Directive 2000/43/EC, 2000 O.J. (L180/22) (EU). In addition there exist a variety of Directives prohibiting gender discrimination. The latter have recently been codified, with regard to employment, in the so-called Recast Directıve. Council Directive 2006/54/EC, 2006 O.J. (L 204/23) (EU) (on the implementation of the principle of equal opportunities and equal treatment of men and women in matters of employment and occupation (recast)). 
reasonable accommodations to meet the needs of disabled individuals, unless this would amount to a disproportionate burden. The reasonable accommodation obligation was new, and indeed unknown, to most of the legal systems of the Member States prior to the adoption of the Directive. It is, moreover, a complex requirement. In spite of this, the Directive only provided limited guidance on what was meant by the obligation and Member States were, for the most part, left in the dark when it came to transposing and interpreting the provision.

The purpose of this article is to consider how the Member States of the European Union have responded to this challenge. ${ }^{3}$ The article reflects on the steps taken by a number of Member States to incorporate the reasonable accommodation obligation into their national law and, specifically, focuses on how the concept of "reasonableness" has been understood and interpreted. At first sight this notion may not seem particularly controversial or confusing; however, an analysis of the concept of "reasonable accommodation" in the Directive, and the relevant transposition legislation, reveals that the term is capable of conveying a number of meanings. Furthermore, a review of the transposition legislation reveals that Member States have indeed conferred different meanings on the term, and there is certainly no common understanding of what a "reasonable" accommodation is. This confusion is also reflected in the case law of the jurisdiction whose legislation arguably provided the inspiration for the inclusion of the reasonable accommodation requirement in the Directive-namely the United States, and this is also considered below.

The article will begin by briefly introducing Article 5 of the Employment Equality Directive and discussing the meaning of the

3. However, the issue of how to implement and interpret the obligation to provide a reasonable accommodation is topical not only in the European context. In December 2006 an agreement was reached on the United Nations Convention on the Rights of Persons with Disabilities. The Convention came into force on May 3, 2008, a month after it had been ratified by twenty states. Among the many obligations that the Convention imposes on States Parties, is ensuring "that reasonable accommodation is provided to persons with disabilities in the workplace." United Nations Convention on the Rights of Persons with Disabilities art. 27(1)(i), Dec. 13, 2006, G.A. Res. 61/106, U.N. Doc. A/RES/61/106 (Jan. 24, 2007). Even though other provisions of the Convention extend the reasonable accommodation beyond the employment sphere, the generic definition of reasonable accommodation found in Article 2 of the Convention bears marked similarities with the definition found in Article 5 of the Employment Equality Directive. The provision reads: " 'Reasonable accommodation' means necessary and appropriate modification and adjustments not imposing a disproportionate or undue burden, where needed in a particular case, to ensure to persons with disabilities the enjoyment or exercise on an equal basis with others of all human rights and fundamental freedoms." Id. art. 2. It can be expected that States that have ratified the Convention will, as in Europe, struggle with the correct transposition and implementation of this requirement. 
notion of an "accommodation." The article will then proceed to discuss the different meanings that the term "reasonable" is capable of conveying and, through an analysis of legislation and case law, establish how various Member States have chosen to transpose the provision. Case law of the U.S. courts, which have also struggled with this concept, will be considered as well. The article will conclude with a discussion of the possible significance of the differing approaches from a European perspective.

\section{ARTICLE 5 OF THE EMPLOYMENT EQUALITY DIRECTIVE-THE OBLIGATION TO MAKE A REASONABLE ACCOMMODATION}

Article 5 of the Directive creates the obligation for employers to make a reasonable accommodation for disabled people:

In order to guarantee compliance with the principle of equal treatment in relation to persons with disabilities, reasonable accommodation shall be provided. This means that employers shall take appropriate measures, where needed in a particular case, to enable a person with a disability to have access to, participate in, or advance in employment, or to provide training for such a person, unless such measures would impose a disproportionate burden on the employer. When this burden is, to a sufficient extent, remedied by existing measures as an element of disability policy in the Member State, it should not be considered disproportionate." ${ }^{4}$

In spite of the many intricacies involved in establishing and assessing reasonable accommodation requirements, this provision is relatively brief. By contrast, the Americans with Disabilities Act (ADA) of 1990, which is considered below, contains a far more detailed set of provisions on reasonable accommodation, and is accompanied by lengthy explanatory guidance. ${ }^{6}$ Nevertheless, EC law does provide a limited amount of further information in the (nonbinding) Preamble to the Employment Equality Directive. Recital 20 expands on the kinds of measures that could amount to a reasonable accommodation: "Appropriate measures should be provided, i.e. effective and practical measures to adapt the workplace to the disability, for example adapting premises and equipment, patterns of

4. One should note that Article 5 of the Employment Equality Directive only sets minimum standards. This means, for example, that Member States are free to impose a requirement on employers to provide accommodations that do more than simply enable a disabled person "to have access to. participate in, or advance in employment, or to provide trainıng."

5. 42 U.S.C. $\$ 12101(2000)$.

6. 29 C.F.R. $\$ 1630.2(0)(2007)$. 
working time, the distribution of tasks or the provision of training or integration resources."

The Preamble also gives some guidance with regard to assessing whether any particular accommodation amounts to a disproportionate burden in Recital 21: "To determine whether the measures in question give rise to a disproportionate burden, account should be taken in particular of the financial and other costs entailed, the scale and financial resources of the organisation or undertaking and the possibility of obtaining public funding or any other assistance."

As noted above, the ADA also imposes an obligation on employers $^{7}$ (and others) to make reasonable accommodations for disabled people. It is submitted that this U.S. statute directly influenced the drafting of Article 5 of the Equality Employment Directive. In particular, it is submitted that the term "reasonable accommodation," first used in the context of the U.S. Rehabilitation Act of $1973^{\circ}$ and later incorporated in the ADA, was determinant of the terminology used in Article 5. A conscious choice was made to use the term "reasonable accommodation" in the Directive because of the level of familiarity with this particular element of the ADA among relevant Commission staff, some Member States, and disability nongovernmental organizations, which lobbied for the inclusion of such a requirement in the Directive. However, as will be revealed below, this may not necessarily have been a wise choice, as the concept of "reasonableness" with regard to accommodations has also proved confusing in the context of U.S. law.

\section{WHAT IS AN “ACCOMMODATION"?}

In this context an accommodation is simply an adaptation to normal procedures, processes, or infrastructure. The goal of any accommodation under Article 5 of the Employment Equality Directive is to enable a person with a disability "to have access to, participate in, or advance in employment." Assessing what kind of accommodation will achieve this goal, and therefore what kind of accommodation is required, involves an individual analysis taking into account the situation of the individual and the employment or training at issue. As a consequence it is not possible for legislation to provide a definitive list of appropriate and required accommodations. Legislation can, however, provide a generic definition accompanied

7. See 42 U.S.C. $\S 12111$ (9) (2000).

8. Regulations were adopted that imposed a duty of reasonable accommodation with regard to Section 504 of the Rehabilitation Act. See 29 C.F.R. §§ 32.13(a), 1613.704 (1995). 
by an illustrative list of appropriate kinds of accommodation, and this approach has been followed in a number of Member States. Furthermore, case law that establishes the duty to (not) make certain accommodations in specific circumstances can also clarify the requirement.

Many Member States have opted to use the terminology of the Directive in their national legislation when transposing Article 5. However, in some jurisdictions the word "accommodation" has been replaced with another term. In the United Kingdom, legislation requires the making of reasonable "adjustments"; 9 Finnish law refers to "steps";" whilst the Irish Employment Equality Act 1998-2004" and the French Labour Code, ${ }^{12}$ drawing their inspiration from Recital 20 to the Directive, define a reasonable accommodation as an "appropriate measure." This term is also found in the Lithuanian Law on Equal Treatment ${ }^{13}$ and the Slovakian Act on Equal Treatment in Certain Areas and Protection Against Discrimination. ${ }^{14}$ However, it is submitted that the use of an alternative term to replace "accommodation" is of no legal significance, and that in essence all of the terms referred to above convey the same meaning.

\section{What Is A "REASONABLE"ACCOMMODATION?}

In contrast, the meaning of the term "reasonable" is far more complex and confused. It is clear that the term serves the role of a modifier to the requirement to provide an "accommodation." At first sight it may appear that the term is capable of only carrying one meaning-namely, the term "reasonable" implies that an employer is only obliged to take action that does not result in excessive costs, difficulties, or problems-anything else would be "unreasonable." This would seem to be in accordance with the everyday meaning attributed to the term "reasonable" and indeed many Member States have transposed the provision in this way. However, an analysis of the national transposition legislation, and a consideration of the judicial discussions that have occurred in the United States in relation

9. The Disability Discrimination Act 1995, c. $50, \S \S 3 \mathrm{~A}, 4 \mathrm{~A}, 18 \mathrm{~B}$ (Eng.). The original version of this statute was in force prior to the adoption of the Employment Equality Directive.

10. Non-Discrimination Act, c. $21 / 2004, \S 5$ (Fin.).

11. Employment Equality Act, 1998-2004. § 16 (Ir.).

12. Code du Travail [C. TRav.], art. L. 323-9-1 (Fr.).

13. Law on Equal Treatment, 2003, No. 9-1826, art. 5 (Lith.), available at http://www.lygybe.lt/ci.admin/Editor/assets/Law\%20on\%20Equal\%20Treatment.doc.

14. Act on Equal Treatment in Certain Areas and Protection Against Discrimination, § 7 (Slovk.). 
to the meaning of the term reveal that alternatively, or in addition, the term "reasonable," or another selected adjective, could relate to the quality of the accommodation itself and mean, for example, that the accommodation must be "effective." Therefore, one can identify two ways in which the term can modify the requirement to make an accommodation. In the first instance, the term modifies the requirement to make the accommodation that is imposed on the employer, whilst in the second, the term is a modifier with regard to the actual accommodation. Indeed, as the analysis below will reveal, in many European jurisdictions the term is (arguably confusingly) used to convey both meanings.

This following section begins by examining the proposition that a "reasonable" accommodation is one that does not result in "excessive" difficulties being experienced by the employer and considering jurisdictions that have adopted this approach. Subsequently, attention will be paid to the alternative interpretation, whereby a "reasonable" accommodation is one that is effective in allowing an individual with a disability to carry out a particular set of employment related tasks, and jurisdictions that have transposed the Directive in this way will be discussed. On occasions, different terminology is used to convey this second meaning. Last, attention will be paid to those jurisdictions where the term is used to convey both the requirement that the accommodation must not result in excessive difficulties for the employer, and must be "effective."

\section{A. A "Reasonable" Accommodation is an Accommodation that Does Not Result in Excessive Costs or Difficulties for the Employer}

Some Member States have transposed Article 5 of the Directive by using the term "reasonable" to limit the obligation to accommodate that is imposed on employers. As a result, employers are only required to make accommodations that do not result in excessive costs or inconvenience. ${ }^{16}$ Any accommodation that has

15. It should be stressed that whilst it has been argued before U.S. courts that a "reasonable accommodation" is one that is "effective" in enabling a disabled individual to carry out the relevant employment related tasks, and the courts have considered this interpretation, the Supreme Court and other senior courts have ultimately not accepted this argument. The relevant U.S. case law is discussed supra.

16. In those jurisdictions which have defined a "reasonable" accommodation as one that is "effective" in allowing a disabled individual to carry out the relevant employment related tasks, a limitation also exists on the obligation imposed on the employer. However, this limitation is generally established through the disproportionate burden defense, rather than (also) through the application of a "reasonableness" test. 
these consequences is, by implication, defined as "unreasonable" and therefore not required under the national law.

This is the approach that has been adopted, for example, in the Finnish Non-Discrimination Act $21 / 2004^{17}$ that obliges employers and trainers to "take any reasonable steps to help a person with disabilities to gain access to work or training, to cope at work and to advance their career."

The Act elaborates on the notion of reasonableness: "In assessing what constitutes reasonable [sic], particular attention shall be devoted to the costs of the steps, the financial position of the person commissioning the work or arranging the training, and the possibility of support from public funds or elsewhere towards the costs involved."

The Preparatory Works ${ }^{18}$ accompanying the Act also throw some light on the meaning of the term reasonable. They state:

The provision would not require implementing unreasonable arrangements. When assessing the reasonableness of the arrangements from the point of view of the employer, the financial costs incurred by the arrangements, the size of the organisation or business and its financial position and the availability of public funding or other support, e.g. for re-arranging working conditions, for example, should be taken into account. Furthermore, arrangements could be deemed unreasonable in situations in which such arrangements would excessively change the activities of the workplace and at the same time could endanger compliance with workplace safety legislation, for example.

In essence the Finnish statute and Preparatory Works refer to three elements in determining whether any accommodation would be reasonable: the cost of the accommodation for the employer, the need to make (excessive) changes to the activities of the workplace, and compliance with workplace safety legislation. The term is therefore clearly, and exclusively, used as modifier to the obligation that is imposed on employers to make an accommodation.

At this point it is appropriate to note that Article 5 of the Directive provides for a second modifier, or limitation, on the obligation to make an accommodation. Namely employers are not required to make an accommodation where this would result in a disproportionate burden. ${ }^{19}$ Where Member States have opted to only

17. Non-Discrimination Act, 2004, c. 21/3004, $\$ 5$ (Fin.).

18. PREPARATORY WORKS TO THE FINNISH NON-DisCRIMINATION ACT, HE 44/2003 [GOVERNMENT PROPOSAL 44/2003] CONCERNING SECTION 5 (Fin.).

19. For an extensive commentary on the meaning of this term, and for an analysis of how it has been transposed into the national legislation of the EU Member States, see Lisa Waddington, Reasonable Accommodation, in CASES, MATERIALS AND TEXT ON NATIONAL, 
require employers to make accommodations that are regarded as "reasonable," how do the two limitations interact? Are these regarded as two separate defenses that can be used to justify a failure to make an accommodation, with the former being far easier to satisfy than the latter, or are they merged into one common defense?

In the case of the Finnish legislation, unusually, no express reference is made to the notion of "disproportionate burden." Instead the legislation relies solely on the notion of "reasonableness" to limit the obligation. Therefore, employers are required to take "steps" to enable an individual with a disability to pursue employment related activities unless this would be unreasonable, as defined in the statute and preparatory works. The reasonableness test is therefore a substitute for the disproportionate burden defense that is found in most other jurisdictions.

In contrast other jurisdictions that define a "reasonable" accommodation as one that is not excessively costly or inconvenient sometimes also specify that a "reasonable" accommodation is one that does not create a disproportionate burden, thereby linking the two notions. This is the approach found in the original transposition legislation that was adopted at the federal level in Belgium. ${ }^{20}$ The relevant statute stated: "A reasonable accommodation is an accommodation that does not create a disproportionate burden, or where the burden is sufficiently compensated for by existing measures."21 Belgian federal legislation therefore only required an accommodation that did not result in a disproportionate burden. ${ }^{22}$ Such an accommodation was, by definition, a reasonable accommodation.

A third approach can be found in German legislation, which clearly separates the requirement of reasonableness from the

SUPRANATIONAL AND INTERNATIONAL NON-DiSCRIMINATION LAW $\S 6.4$ (D. Schiek. L. Waddington \& M. Bell eds.. 2007).

20. Act of 25 February 2003 to Combat Discrimination and to Amend the Act of 15 February 1993 to Establish a Centre for Equal Opportunity and to Combat Racism, 2003 (Belg.). For more extensive commentary on this Act see Lisa Waddington. Implementing the Disability Provisions of the Framework Employment Directive: Room for Exercising National Discretion, in Disability Rights in Europe, From TheORY TO PRACTICE 107 (Anna Lawson \& Caroline Gooding eds., 2005), and articles published in the collection VRIJHEID EN GELIJKHEID, DE HORIzONTALE WERKING VAN HET GELIJKHEIDSBEgINSEL EN DE NIEUWE ANTIDUSCRIMINATIE WET (2003). This statute has recently been repealed and replaced by the Act of 10 May 2007 to Combat Certain Forms of Discrimination.

21. Act of 25 February 2003 to Combat Discrimination and to Amend the Act of 15 February 1993 to Establish a Centre for Equal Opportunity and to Combat Racism, 2003. art. 2(3) (Belg.).

22. Or an accommodation where the burden is "sufficiently compensated for by existing measures," such as public subsidies, which render it no longer "disproportionate." 
disproportionate burden defense - with both concepts being used to limit the obligation imposed on the employer. The German Social Law Code, ${ }^{23}$ which was not adopted with a view to implementing Article 5 of the Directive, imposes duties on employers with regard to accommodating severely disabled workers, but subjects this to the requirement that the fulfillment of the worker's claim for an accommodation must be reasonable for the employer. The Code provides:

Duties of employers and rights of severely disabled persons

(4) The severely disabled persons have a right against their employer

1. to be employed in a way that allows them to utilize and improve their skills and knowledge to the fullest extent possible,

2. to be preferentially considered for internal vocational training measures for furtherance of their professional progress,

3. to facilitations to a reasonable extent regarding participation in external vocational training measures,

4. to adaptation and maintenance of the workplaces suitable to the disability, including operating equipment, machines and devices as well as the design of the workplace, the working environment, the work organisation and the working time, taking risk of accident particularly into consideration,

5. to equipment of the workplace with the necessary technical working aids taking the disability and its effects on the occupation into consideration.... A claim ... does not exist if its fulfilment is not reasonable for the employer or if it would entail disproportionate burden or in as far as the occupational safety and health rules laid down by national law or by employer's liability insurance associations or rules governing members of the civil service are opposed.

It is interesting to note that, in some respects, the obligations imposed on employers under German law go beyond those referred to in Article 5 of the Employment Equality Directive. For example, employers are, in principle, obliged to ensure that disabled persons are employed in a way that allows "them to utilize their skills and knowledge to the fullest extent possible" and to be preferentially considered for internal vocational training. Both of these requirements go beyond participating in employment, as referred to in Article 5. On the other hand, there is no clear reference to enabling disabled people "to have access to ... employment" in the Social Law

23. Sozialgesetzbuch [SGB] (Social Insurance Code) June 19, 2001, Reichsgesetzblatt [RGBl] 1046, § 81 (F.R.G.). 
Code, which could certainly include the making of accommodations at the recruitment stage.

Turning to the relationship between the accommodations required, and the accepted justifications for failing to make those accommodations, German law requires that, in principle, employers must make an accommodation (in the first sentence of section 81(4) SGB IX), and, quite separately, sets out the grounds on which an employer might justifiably refuse to do so (in sentence 2). ${ }^{24}$ This clearly defined two-staged approach is also found in other jurisdictions, such as the Netherlands and the United States. ${ }^{25}$ It contrasts with the "merged" approach found under the (now repealed) Belgian federal law outlined above. According to paragraph 5 of section 81(4) of the German Social Law Code, a severely disabled individual is not entitled to claim the right specified in paragraphs one through five if one (or more) of three conditions is met, namely the fulfillment of the claim would:

- be not reasonable for the employer;

- result in a disproportionate burden for the employer; or,

- $\quad$ result in the breach of health and safety rules.

The concept of reasonableness is therefore once again used as a limitation on the actions that can be expected of the employer. In addition, and in contrast to Finnish and (repealed) Belgian law, the concept is distinct from two other defenses to the requirement to make an accommodation-namely that this would result in a disproportionate burden for the employer or breach health and safety rules. The implication is that an accommodation might not result in a disproportionate burden or pose a threat to health and safety standards, but could still not be required of the employer on the grounds that it would be unreasonable. However, the exact requirements for determining whether making any accommodation

24. It is worth noting that the approach adopted in the German Social Law Code is unusual in that it is framed in terms of a positive right for a covered person with a disability, which allows the individual to claim an adaptation or other work related benefit. Furthermore, this right is provided for in the Social Law Code, which is not a non-discrimination statute. In contrast the General Equal Treatment Act of 2006, which was adopted to transpose the Employment Equality Directive, inter alia, and which covers disability discrimination in the areas of employment and civil law, makes no explicit reference to reasonable accommodations. Finally, the entitlement to claim an accommodation is confined to people who have been classified as "severely" disabled. which arguably excessively limits the personal scope of the protection, and is a breach of the Directive.

25. Both are considered below. 
would be unreasonable, or result in a disproportionate burden, are not set out in the legislation.

In none of the jurisdictions considered above have the courts been required to analyze the meaning of the term "reasonable," and to adjudicate between the two possible meanings that were presented at the very beginning of this section. However, this has happened in the United States, which has a much longer experience of working with the reasonable accommodation requirement in the context of disability. It is therefore worth considering how the U.S. legislature and courts have interpreted the concept.

The Americans with Disabilities Act (ADA) defines discrimination as including a failure to make a reasonable accommodation, unless making the accommodation would result in an "undue hardship." The latter term is used in preference to the phrase "disproportionate burden," which is found in the Employment Equality Directive. The U.S. statute adopts a two-stage process. Under the ADA in principle an obligation to make a reasonable accommodation exists; once it has been established that such an accommodation is possible, the employer can still demonstrate that to make the accommodation would lead to an undue hardship, and it is therefore not required. As a consequence of this two-stage approach, the "reasonableness" of the statute is assessed quite separately from the question of undue hardship.

The Equal Employment Opportunity Commission (EEOC), which is the federal agency charged with the administrative and judicial enforcement of federal civil rights laws with regard to employment, has issued guidance on how the term "reasonable accommodation" should be interpreted. Their regulations on the ADA define the term as follows:

(i) Modifications or adjustments to a job application process that enable a qualified applicant with a disability to be considered for the position such qualified applicants desires; or

(ii) Modifications or adjustments to the work environment, or to the manner or circumstances under which the position held or desired is customarily performed, that enable a qualified individual with a disability to perform the essential functions of that position; or

(iii) Modifications or adjustments that enable a covered entity's employee with a disability to enjoy equal benefits and privileges of employment as are enjoyed by its other similarly situated employees without disabilities.

In light of the EEOC Guidance one could argue that an accommodation is reasonable if it allows a qualified individual with a 
disability to achieve one or more of the goals set out above. This interpretation is arguably supported by a House of Representatives Labor Report on the ADA that states: "A reasonable accommodation should be effective for the employee ... [and] should provide a meaningful equal employment opportunity ... [that is] an opportunity to attain the same level of performance as is available to non-disabled employees having similar skills and abilities." 26

However, in recent litigation before senior U.S. courts, including the Supreme Court, this argument has been rejected and the courts have regarded the term "reasonable" as a modification to the requirement that is imposed upon the employer, albeit a modification that is quite separate from the undue hardship defense.

In Vande Zande ${ }^{27}$ the plaintiff argued that the term "reasonable" referred to the qualities of the requested accommodation, and simply implied that the accommodation should be "apt or efficacious." Any accommodation that was "tailored to the particular individual's disability" was reasonable, and the cost of the accommodation was a matter exclusively for consideration under the "undue hardship" test. However Judge Posner, sitting on the bench of the 7 th Circuit, rejected this argument. He found:

To "accommodate" a disability is to make some change that will enable the disabled person to work. An unrelated, inefficacious change would not be an accommodation of the disability at all. So "reasonable" may be intended to qualify (in the sense of weaken) "accommodation," in just the same way that if one requires a "reasonable effort" of someone this means less than the maximum possible effort, or in law that the duty of "reasonable care," the cornerstone of the law of negligence, requires something less than the maximum possible care.

He continued by holding that the question of cost of the accommodation was not only relevant in determining whether an undue hardship existed, but also entered into the consideration of whether any accommodation was reasonable or not:

it seems that costs enter at two points in the analysis of claims to an accommodation to a disability. The employee must show that the accommodation is reasonable in the sense both of efficacious and of proportional to costs. Even if this prima facie showing is made, the employer has an opportunity to prove that upon more careful consideration the costs are excessive in relation either to the benefits of the accommodation or to the employer's financial survival or health....

26. H.R. ReP. NO. 1001-485, at 66 (1990).

27. Vande Zande v. Wisconsin Dep't of Admin., 44 F.3d 538 (7th Cir. 1995). 
The court therefore clearly rejected the argument that an accommodation was "reasonable" if it was effective and tailored to the needs of an individual with a disability. Instead the court saw the term "reasonable" as serving to modify ("in the sense of weaken") the accommodation itself. In doing so, Judge Posner, who is a leading advocate of "law \& economics," drew inspiration from the law of negligence, and stated that the term "reasonable" implied the cost of making the accommodation to the employer should not be disproportionate to the benefit. Therefore, even if making a particular accommodation would not result in a disproportionate burden for the employer, and if the accommodation would result in a benefit to the individual with the disability, the accommodation need not be made if it would be unreasonable: the employer "would not be required to expend enormous sums in order to bring about a trivial improvement in the life of a disabled employee." The proportionality principle was therefore built into the calculation of whether any accommodation is reasonable or not. However, whilst Judge Posner clearly felt that a proper assessment of the "reasonableness" of any accommodation required a cost-benefit analysis, meaning that the accommodation should be expedient and proportionate to the resulting benefits, he did not further elaborate on the formula to be applied. $^{28}$

The U.S. Supreme Court also has been called upon to consider the meaning of the term "reasonable" in the case of U.S. Airways v. Barnett. ${ }^{29}$ In this case the plaintiff once again argued that the phrase "reasonable accommodation" meant only "effective accommodation," and the court should only consider whether the requested accommodation met an individual's disability-related needs. In making this argument Barnett relied on inter alia the EEOC regulations and House of Representatives Report quoted above. However the Supreme Court was not convinced by these arguments

28. For a criticism of Judge Posner's judgment in Vande Zande on the grounds that it did not seriously analyze either costs or benefits, or sufficiently take into account the stigmatic harms and daily humiliations that disabled people experience, see Cass R. Sunstein, Cost-Benefit Analysis without Analyzing Costs or Benefits: Reasonable Accommodation, Balancing, and Stigmatic Harms, (Univ. of Chicago John M. Olin Law \& Economics Working Paper No. 325. 2007), available at https:/www.law.uchicago.edu/Lawecon/wkngPprs_301-350/325.pdf. For a thoughtful discussion as to how a law and economics approach can be used to analyze accommodation claims, see Michael Ashley Sten, The Law and Economics of Disability Accommodations, 53 DUKE L. REV. 79 (2003).

29. U.S. Airways, Inc. v. Barnett, 535 U.S. 391 (2002). For commentary see Samuel R. Bagenstos, US Airways v. Barnett and the Limits of Disability Accommodation (Washington Unıv. Sch. of Law, Working Paper No. 07-01-02, 2007), available at http://ssrn.com/abstract=953759. 
and held: "For one thing, in ordinary English the word 'reasonable' does not mean 'effective.' It is the word 'accommodation,' not the word 'reasonable,' that conveys the need for effectiveness. An ineffective 'modification' or 'adjustment' will not accommodate a disabled individual's limitations." [emphasis in original]

Whilst the U.S. courts have had the opportunity to find that the term "reasonable" should act as a modifier to the actual accommodation, and mean that the accommodation should meet the needs of the disabled individual, they have firmly rejected this interpretation in recent years. Instead, any claim for an accommodation in the United States must both be reasonable, and not result in an "undue hardship" for the employer. The case law suggests that it is easier to establish that an accommodation is not reasonable than to prove an undue hardship and that even very minor and cheap accommodations-such as the lowering of a sink requested by the wheelchair user Vande Zande-can be rejected on the grounds that they are not reasonable.

\section{B. A "Reasonable Accommodation" Is an Accommodation that is Effective in Meeting the Needs of the Disabled Individual}

In this section an alternative understanding of the term is considered, namely that an accommodation is regarded as reasonable if it is effective in allowing the beneficiary to carry out (employmentrelated) tasks. Given that the term "reasonable" is not easily capable of conveying such a meaning, legislators generally opt to use an alternative term, or elaborate on the meaning of the term "reasonable," if they favor such an approach.

A leading example of a jurisdiction that has chosen to transpose Article 5 of the Directive in this way is the Netherlands. Article 2 of the Dutch Act on Equal Treatment on Grounds of Disability or Chronic Illness 2004 provides: "The prohibition of making distinction $^{30}$ also includes the duty for the person to whom the

30. Dutch law does not make use of the term "discrimination," but instead uses the term "distinction" in all its non-discrimination statutes. It has been argued that Dutch legal theory perceives the term "discrimination" (discriminatie in Dutch) as an asymmetrical and grouporiented concept, and that the combating of "discrimination" is regarded as a tool to be used to target and benefit disadvantaged social groups (i.e., based on a substantive concept of equality). See T. Loenen, Het Gelijk heidsbeginsel (1998) and R. Holtmaat, Stop de inflatie van het discriminatiebegrip, 23 NederLandS JURISTENBLAD 1266 (2003). However, Dutch equal treatment law, including the well-known General Equal Treatment Act, does not adopt this group-based perspective but, instead, takes an individualistic and symmetrical approach (i.e., a formal approach to equality). The term discrimination is therefore a highly loaded and pejorative term, and carries a much greater weight than the same term in English. Instead, as 
prohibition is addressed, to make effective accommodations in accordance to the need for this, unless doing so would constitute a disproportionate burden upon her." 31

The Dutch statute therefore does not require a "reasonable accommodation," but instead establishes a duty to make "effective accommodations." The Dutch government explained its decision to use the latter term on the grounds that this was preferable as it better reflected the fact that an accommodation had to achieve the pursued effect. $^{32}$ This approach also has the advantage of establishing a clearly defined two-stage test to establish whether an employer is obliged to make an accommodation. One must first establish whether any "effective accommodation" is possible and then, quite separately, consider whether making such an accommodation would amount to a "disproportionate burden."

Whilst the term "effective accommodation" itself is not defined in the Act on Equal Treatment on the Grounds of Disability or Chronic Illness, one can conclude from the Explanatory Memorandum that accompanied the adoption of the Act, that the first stage of the test to establish whether an employer, or other covered entity, is under an obligation to provide an accommodation involves asking two separate questions:

1. Is the accommodation that is being considered suitable and appropriate, i.e., does it enable the individual with a disability to carry out the job?

2. Is the accommodation that is being considered necessary (i.e. a pre-condition to do the job)?

noted, Dutch equal treatment law uses the term "distınction"("onderscheid"), which is regarded as a neutral concept. For a more detailed examination in Englısh, see Lisa Waddington, Implementing the Disability Provisions of the Framework Employment Directive: Room for Exercising National Discretion, in DISABILITY RIGHTS IN EUROPE, FROM THEORY TO PRACTICE 122, 122-24 (Anna Lawson \& Caroline Gooding eds.. 2005).

31. For a more detailed overview of Article 2 of the Dutch Act on Equal Treatment on Grounds of Disability or Chronic Illness 2004 in the context of the obligations imposed under the Employment Equality Directive, see RIKKI HOLTMAAT, REPORT ON MEASURES TO COMBAT DISCRIMINATION, DIRECTIVES 2000/43/ EC AND 2000/78/EC. COUNTRY REPORT, THE NETHERLANDS, 2007, available at $\mathrm{http}: / / \mathrm{ec}$.europa.eu/employment_social/fundamental_rights/ pdf/legnet/nlrep07_en.pdf

32. Gelijke behandelıng op grond van handicap of chronische ziekte, memorie van toelichting [Equal treatment on the ground of disability and chronic disease, Explanatory Memorandum, Second Chamber of Parliament] 2001-02 (Neth.); see also M. Gijzen, Het nieuwe gelijkebehandelingsrecht voor gehandicapten en chronisch zieken, in OORDELENBUNDEL 105 (2003) (Neth.). 
If both of these questions have been answered in the affirmative, the "(dis)proportionality" of the burden on the part of the employer can be assessed.

The Dutch Equal Treatment Commission, which is the semijudicial body charged with hearing complaints of unlawful distinction, ${ }^{33}$ has considered the meaning of Article 2 of the Act in a number of Opinions. In Opinion 2004-140 34 the Commission considered the extent to which it was possible to charge higher fees to students who, as a result of a disability, required additional time to complete their examinations. ${ }^{35}$ The Commission discussed the standard to be applied to determine whether any accommodation was effective and elaborated on the dual test, consisting of the elements of appropriateness and necessity, outlined in the Explanatory Memorandum. The Commission concluded that an accommodation was appropriate if it could eliminate impediments to participation in social life and could promote the independence and full participation and integration of the individual in question. These goals seem to go beyond the mere elimination of employment related distinctions on the ground of disability, and embrace an agenda for social change. The Commission also concluded that an accommodation was necessary if the same objective could not be achieved with another, possibly less expensive, provision and referred to a number of factors that could be considered, including medical or ergonomic advice and the contribution of the person with a disability in determining whether any accommodation was effective. In a later Opinion ${ }^{36}$ the Commission stressed that "a characteristic of an effective accommodation is precisely one tailored to the individual (or his situation)." In reaching this conclusion the Commission referred, inter alia, to Article 5 of the Employment Equality Directive.

Another jurisdiction in which a reasonable accommodation is regarded as one that is effective in meeting the needs of a disabled individual is Ireland. An obligation to make a reasonable accommodation for disabled individuals already existed under Irish law, in the Employment Equality Act 1998, prior to the adoption of

33. Plaintiffs can also take action before the conventional courts.

34. The full text of the Opinions of the Equal Treatment Commission are available (in Dutch) via their homepage http://www.cgb.nl

35. The exam in question related to vocational qualification, and therefore came within the scope of the Employment Equality Directive. The Commission concluded that, by charging extra for such exams, the examination board made an unlawful distinction on the grounds of disability.

36. Equal Treatment Commission Opinion 2005-18, avallable at http://www.cgb.nl/opinionfull.php?id=453055515. 
the Directive. However, the Directive required important amendments to Irish domestic law. These were enacted by the Equality Act 2004 that, inter alia, amended section 16 of the aforementioned Employment Equality Act as follows:

(3)(a) For the purposes of this Act a person who has a disability is fully competent to undertake, and fully capable of undertaking any duties if the person would be so fully competent and capable on reasonable accommodation (in this subsection referred to as "appropriate measures") being provided by the person's employer.

(b) The employer shall take appropriate measures, where needed in a particular case, to enable a person who has a disability -

(i) to have access to employment,

(ii) to participate more advanced in employment, or

(iii) to undergo training

unless the measures would impose a disproportionate burden on the employer.

$* * *$

subsection (4)...

"appropriate measures", in relation to a person with a disability -

(a) means effective and practical measures, where needed in a particular case, to adapt the employer's place of business to the disability concerned,

(b) without prejudice to the generality of paragraph (a), includes the adaptation of premises and equipment, patterns of working time, distribution of tasks or the provision of training or integration resources, but

(c) does not include any treatment, facility or thing that the person might ordinarily or reasonably provide for himself or herself.

While the Equality Act uses the term "reasonable accommodation," it defines such an accommodation as an "appropriate measure." A measure is regarded as appropriate if it is effective in allowing an individual with a disability to have access to employment related activities. An appropriate measure is not required if it would result in a disproportionate burden for an employer. However, the existence of a disproportionate burden does not detract from the fact that the measure would still be appropriate.

Likewise the French legislature has opted to refer to an obligation to take appropriate measures (measures appropriées) rather than reasonable accommodations (aménagements raisonnables) when 
amending the Labor Code to render it compliant with the Employment Equality Directive. ${ }^{37}$ Article L.323-9-1 therefore provides that "employers shall take appropriate measures as a function of concrete needs" to meet the employment related needs of covered disabled workers, unless this would leads disproportionate expenses.

The decision of the Dutch, Irish, and French legislatures to define a reasonable accommodation as one that is "effective" or "appropriate" in allowing the covered disabled individual to meet the relevant employment related requirements can be welcomed for the clarity that it brings to a complicated process. However, this does not necessarily imply that the concept of "effectiveness" or "appropriateness" is interpreted in an identical manner in these jurisdictions. $^{38}$ It remains possible to justify a failure to make a reasonable accommodation, through the disproportionate burden defense or equivalent thereof, in all of these jurisdictions, but this examination is not merged with the first issue of whether an effective or appropriate accommodation is theoretically possible.

C. A "Reasonable Accommodation" Is an Accommodation That Does Not Result in Excessive Costs or Difficulties for the Employer and Is Effective in Meeting the Needs of the Disabled Individual

The previous sections have considered how the term "reasonable," or a substitute term, can either imply that the accommodation must not result in excessive costs or difficulties for the employer, or can signify that the accommodation must be effective or appropriate. This section considers how the term "reasonable" can be used to convey the dual meaning that any accommodation must

37. Law No. 2005-12 of February 11, 2005, Journal Officiel de la Republique Française [J.O.] [Official Gazette of France], February 12, 2005. It states:

In order to guarantee respect for the principle of equal treatment for disabled workers mentioned in article L. 323-3, employers shall take the appropriate measures as a function of concrete needs, to allow the workers mentioned in items $1,2,3,4,9,10$ and 11 of Article L. 323-3 access to a job or to keep a job corresponding to their qualifications, to carry out or progress towards the same or to allow the same workers to receive training adapted to their needs, subject to the provision that expenses resulting from the implementation of these measures are not disproportıonate, considering the assistance which may compensate the expenses incurred by the employer in this capacity in whole or in part. This assistance may notably relate to the adaptation of machines or equipment, the provision of jobs, including the individual support or equipment necessary for disabled workers to occupy these positions, and the access to their workplaces. A refusal to take the appropriate measures pursuant to the first paragraph may constitute discrimination, pursuant to Article L. 122-45-4.

38. This is of course also true when making a comparison with the way in which U.S. judges have understood the concept of "effectiveness." 
both not result in excessive difficulties for the employer and be effective.

At this stage it seems appropriate to return to Article 5 of the Employment Equality Directive, since, although the Directive does not clearly elaborate on the meaning of the term "reasonable," a number of provisions suggest that the intention may have been that the term be understood to mean that any accommodation must be effective in allowing an individual with a disability to participate in employment related activities while not resulting in an excessive burden for the employer. The Article states that "reasonable accommodation shall be provided" and explains that as meaning: "that employers shall take appropriate measures, where needed in a particular case, to enable a person with a disability to have access to, participate in, or advance in employment, or to undergo training, unless such measures would impose a disproportionate burden on the employer. .." Recital 20 to the Directive's Preamble, which was quoted earlier, then goes on to give examples of the kind of appropriate measures that should be provided.

If we break up Article 5 up into its constituent parts we discover that the obligation to make a reasonable accommodation under the Directive means that: the employer must take "appropriate measures" unless this would result in a disproportionate burden.

It is submitted that this reflects poor drafting, as the justification for failing to make a reasonable accommodation (disproportionate burden) is included within the definition of the obligation to make such an accommodation. Matters would have been clarified if the Directive had clearly stated what the obligation to make a "reasonable accommodation" involved, and, separately specified that employers could rely on the defense that making such an accommodation amounted to a "disproportionate burden."

Nevertheless, one can extract from the text of Article 5, in combination with Recital 20, that a "reasonable accommodation" is any "appropriate measure." A "measure" will be "appropriate" if it is "effective and practical ... to adapt the workplace to the disability" meaning that it should "enable a person with a disability to have access to, participate in, or advance in employment or to undergo training." One could argue that the "reasonableness" requirement therefore firstly relates to the "effectiveness" of the accommodation in allowing employment participation by an individual with a disability. If such an accommodation can be made, the question then arises whether it would amount to a "disproportionate burden." If such a burden will result, then, by definition, the accommodation will 
not be "reasonable." This interpretation implies that under the Directive the "reasonable" requirement is seen as a modifier to both the accommodation itself and the obligation to make an accommodation, by requiring that the measure is both "effective" and not a "disproportionate burden."

Given that the Directive brought the concept of reasonable accommodation to the attention of many European legislators, and indeed "forced" the notion onto these legislators, it is not surprising to find that many national transposition statutes have simply copied, or closely followed, the wording of Article 5. This is the case, for example, with regard to the Latvian Labour Law, ${ }^{39}$ the Greek NonDiscrimination Law, ${ }^{40}$ and the Decree of the Flemish Community of Belgium concerning balanced participation in the labor market. ${ }^{41}$ As a result these jurisdictions have also attributed the dual meaning to the term "reasonable" within their legislation.

On the other hand, the European jurisdiction that has the longest experience of working with the concept of reasonable accommodation, namely the United Kingdom, also seems to follow this approach. The Disability Discrimination Act (DDA) 1995 as amended, which establishes a duty to make reasonable adjustments (rather than reasonable accommodations), provides:

3A Meaning of "discrimination" 42

$* * *$

(2) For the purposes of this Part, a person also discriminates against a disabled person if he fails to comply with a duty to make reasonable adjustments imposed on him in relation to the disabled person.

$* * *$

4A Employers: duty to make adjustments

(1) Where -

(a) a provision, criterion or practice applied by or on behalf of an employer, or

Law,

2001

art.

$7(3)$

(Lat.),

available

at http://www.ttc.lv/New/lv/tulkojumi/E0223.doc.

40. Nomos, (2005:3304) Implementation of the Principle of Equal Treatment Regardless of Racial or Ethnic Origin, Religion or Other Beliefs, Disability, Age or Sexual Orientation. Ephemeris tes Kyvernesos tes Hellenikes Demokratias [EKED] 2005, art. 10 (Greece).

41. Decree of the Flemish Community of May 8, 2002 Concerning Proportionate Participation in the Labour Market, 2002, art. 5 (Belg.).

42. The provisions of the Act are elaborated on in Disability Discrimination Act 1995, Code of Practice, Employment and Occupation, Disabllity Rights Commission. 
(b) any physical feature of premises occupied by the employer; places the disabled person concerned at a substantial disadvantage in comparison with persons who are not disabled, it is the duty of the employer to take such steps as it is reasonable, in all the circumstances of the case, for him to have to take in order to prevent the provision, criterion or practice, or feature, having that effect.

$* * *$

18B Reasonable adjustments: supplementary

(1) In determining whether it is reasonable for a person to have to take a particular step in order to comply with a duty to make reasonable adjustments, regard shall be had, in particular, to -

(a) the extent to which taking the step would prevent the effect in relation to which the duty is imposed;

(b) the extent to which it is practicable for him to take the step; ${ }^{43}$

(c) the financial and other costs which would be incurred by him in taking the step and the extent to which taking it would disrupt any of his activities;

(d) the extent of his financial and other resources;

(e) the availability to him of financial or other assistance with respect to taking the step;

(f) the nature of his activities and the size of his undertaking;

(g) where the step would be taken in relation to a private household, the extent to which taking it would -

(i) disrupt that household, or

(ii) disturb any person residing there.

Section $18 \mathrm{~B}$ of the DDA therefore provides elaboration on determining whether an adjustment is reasonable. Of the points listed under the section, the first relates to the effectiveness of the adjustment, while the remainder relate to the difficulty an employer might experience in making the adjustment. The DDA also establishes a duty to make reasonable adjustments in order to allow people with a disability to access a service. ${ }^{44}$ The Act does not provide any guidance on what might be regarded as reasonable in this context, although the relevant Code of Practice contains a list of factors similar

43. The aforementioned Code of Practice, id., explains this requirement in the following way: "It is more likely to be reasonable for an employer to have to take a step which is easy to take than one which is difficult. In some circumstances it may be reasonable to have to take a step, even though it is difficult." Id. § 5.30. I am grateful to Anna Lawson for providing background information on this point.

44. Disability Discriminatıon Act. 1995, c. 50, §§ 21, 23 (Eng.). 
to those found in section $18 \mathrm{~B}$ relating to employment, namely effectiveness, practicability, cost, disruption, resources, amount already spent on adjustments, and availability of other sources of assistance. $^{45}$

\section{COMPARATIVE OVERVIEW}

The analysis has revealed that there are three different approaches according to which the term "reasonable" can be understood. In the first approach, an accommodation will only be regarded as "reasonable" if it does not impose excessive difficulties or costs on the employer or other covered party. Generally this requirement exists alongside the separate defense that making an accommodation would result in a disproportionate burden or undue hardship. ${ }^{46}$ This implies that an accommodation can be regarded as "unreasonable" and therefore not required, and, in such situations, the (stricter) disproportionate burden test will not be considered. It possibly also implies that an accommodation could be regarded as "reasonable," but not required because it would result in a disproportionate burden. However, in practice, under this approach, it is difficult to conceive of such a situation.

According to the second approach, an accommodation will be regarded as "reasonable" if it is effective in allowing the relevant individual to carry out the necessary (employment related) tasks. Given that the term "reasonable" cannot easily convey this meaning, European jurisdictions that have followed this approach have sensibly used alternative terms. Dutch legislation makes no reference to a "reasonable" accommodation but instead requires an "effective" accommodation, while the Irish Employment Equality Act 1998-2004 defines a "reasonable" accommodation as "appropriate measures," which is also the term found in the French Labor Code. The difficulties of using the term "reasonable" to convey this meaning are illustrated by U.S. legislation and case law. In both Vande Zande and Barnett the complainants sought to argue that a "reasonable" accommodation was one that was "apt or efficacious" (Vande Zande) or "effective" (Barnett). However, in both instances the Courts rejected this interpretation, and held that an accommodation has to be "reasonable," meaning that it should be expedient and proportionate

45. See Disability Discrimination Code of Practice, Disables Persons, 2002, S.I. 2002/720 (U.K.), available at http://www.opsi.gov.uk/s1/si2002/20020720.htm.

46. However, the Finnish legislation only makes use of the "reasonableness" requirement in establishing the limits to making an accommodation. 
to the resulting benefits (Vande Zande) or "reasonable on its face, i.e. ordinarily or in the run of cases" (Barnett). This experience suggests that the Dutch, Irish, and French legislatures have wisely opted to use alternative language to convey the meaning that an accommodation must be effective.

What both approaches outlined above have in common is that they require a two stage test to establish whether any accommodation must be made. First, in principle the employer or other covered party is obliged to make an accommodation. Generally the legislation sets out the objective of any accommodation. On occasions this objective is broad and relatively unelaborated; for example, Finnish law requires that the accommodation must "help a person with disabilities to gain access to work or training, to cope at work and to advance their career," while other legal provisions provide more detail with regard to the objectives pursued. In addition, the German legislation lists five separate rights that could be met through making an accommodation. In contrast Dutch and Irish law stress the effectiveness or appropriateness of any accommodation.

At the second stage the question of whether any defense to the requirement to make an accommodation as defined in the legislation exists. Most legal systems described in these two sections make use of the disproportionate burden defense. However, those described in Section IV.A also combine this with the additional test of "reasonableness," while those considered under Section IV.B rely exclusively on the disproportionate burden defense. In contrast, Finnish legislation only refers to the "reasonableness" of the accommodation in this context. Nevertheless, in effect it can be expected that the "reasonableness" requirement under Finnish law will be interpreted in the same way as the disproportionate burden and "reasonableness" requirements found in other jurisdictions.

The last way in which the term "reasonable" is used in legislation is to convey both that the accommodation must be effective and that it must not impose significant inconvenience or cost on the employer or covered party. This is the approach adopted in the United Kingdom, which has the longest standing reasonable accommodation requirement within the European Union. Given that this approach is also adopted in Article 5 of the Employment Equality Directive, the European Court of Justice will be confronted with the task of interpreting, and thereby enabling national courts to apply, this dual meaning in the future. The Court may draw inspiration from the legal systems identified earlier in this article, which have opted for a twostaged approach to determining whether any accommodation is 
required. However, in doing so the Court will have to delineate clearly the two different meanings of the term "reasonable" in its case law. 